\title{
LANGKAH-LANGKAH KELUARGA DALAM UPAYA PEMBENTUKAN ESQ ANAK
}

\author{
Hikmat Kamal \\ Hikmatkamal70@gmail.com \\ (Dosen Fakultas Agama Islam, Universitas Muhammadiyah Tangerang)
}

\begin{abstract}
Abstrak:
Orang tua sangat berperan dan mereka diminta tanggung jawab, komitmen, dan konsistensinya dalam pendidikan anak orang tua dan lingkungan keluarga harus mampu menciptakan lingkungan yang dapat menjamin berkembangnya seluruh potensi dan kemampuan seorang anak. Langkah-langkah keluarga dalam pembenukan esq adalah:(1)langkah-langkah persiapan melalui pembinaan lingkungan Islami;(2) langkahlangkah pelaksanaan pendidikan anak pra-natal (masih dalam kandungan); (3)langkahlangkah pelaksanaan pendidikan anak setelah lahir pra-remaja; (4)langkah pendampingan di masa anak sudah menginjak dewasa.
\end{abstract}

\section{Kata Kunci: Keluarga, Pembentukan ESQ anak}

\section{A. Pendahulun}

Tujuan pendidikan dalam keluarga adalah agar anak mampu berkembang secara maksimal, baik jasmani, akal, maupun ruhaninya. ${ }^{1}$ Dengan perkembangan yang optimal tersebut diharapkan akan terbentuk kecerdasan anak dalam berbagai bentuknya. Akhirnya anak akan mampu berperan sebagai anggota masyarakat yang baik dan juga sanggup mempertanggungjawabkan segala perilakunya sebagai khalîfat Allâh dan 'Abd Allâh. Untuk itu, orang tua dan lingkungan keluarga harus mampu menciptakan lingkungan yang dapat menjamin berkembangnya seluruh potensi dan kemampuan seorang anak. ${ }^{2}$

\footnotetext{
${ }^{1}$ Abd al-Rahmân al-Nahlawi, Pendidikan Islam di Rumah, Sekolah, dan Masyarakat, terjemahan oleh Sihabuddin, Jakarta, Gema Insani Press, 1995, hlm 27.

${ }^{2}$ Zakiyah Darajat, Berawal dari Keluarga: Revolusi Belajar Cara al-Qur'an, Jakarta, Hikmah, 2002, cetakan ke-1, hlm. xi.
}

Menurut Zakiyah Darajat, ${ }^{3}$ dalam pendidikan keluarga, orang tua sangat berperan dan mereka diminta tanggung jawab, komitmen, dan konsistensinya dalam pendidikan anak. Dengan demikian, tanggung jawab orang tua (keluarga) dalam pendidikan anak cukup signifikan, sebab keluarga merupakan lingkungan yang pertama kali bersentuhan dengan anak. Dari mereka pulalah, anak memperoleh pengetahuan, pengalaman, keterampilan, dan sikap. Oleh karena itu, kualitas orang tua dan lingkungan keluarga sangat dominan dalam pembentukan jiwa dan kerpibadian anak. Dalam pelaksanaan pendidikan anak dalam keluarga menuntut kesungguhan dan kecermatan orang tua, pengetahuan orang tua tentang berbagai materi, metode dan pola pelaksanaan pendidikan akan sangat menentukan keberhasilan dari proses pendidikan di dalam keluarga, dan ketika dilakukan dengan seranpangan dan seadanya maka

${ }^{3}$ Zakiyah Darajat, Berawal dari Keluarga: Revolusi Belajar Cara al-Qur'an, Jakarta, Hikmah, 2002, cetakan ke-1, hlm. xi. 
hasil yang diharapkan tidak akan tercapai dengan baik

Langkah-langkah keluarga dalam upaya mewujudkan kecerdasan emosional pada persiapan tersebut belumlah cukup, tetapi harus dilengkapi dengan mengikuti langkah-langkah tertentu seperti yang diajarkan oleh Islam tentang pendidikan anak.

\section{B. Langkah-Langkah Keluarga dalam Upaya Pembentukan ESQ Anak}

Langkah-langkah tersebut adalah: (1)langkah-langkah persiapan melalui pembinaan lingkungan Islami; (2) langkahlangkah pelaksanaan pendidikan anak pranatal (masih dalam kandungan); (3)langkah-langkah pelaksanaan pendidikan anak setelah lahir pra-remaja; (4)langkah pendampingan di masa anak sudah menginjak dewasa.

\section{Langkah-Langkah Persiapan (Masa Sebelum Mengandung)}

Di antara langkah-langkah itu adalah a) memilih pasangan hidup yang seiman dan shaleh (shalehah), b) menghormati orang tua, dan c) mendo'akan (calon) anak.

\section{a. Memilih Pasangan Hidup yang Seiman dan Shaleh (shalehah)}

Mendidik anak, dapat dimulai sejak pemilihan jodoh. Upaya untuk itu dimulai dari memilih calon istri/suami yang beragama (taat beribadah). Kemudian, jika kesepakatan perkawinan sudah diperoleh, dilanjutkan dengan upacara-upacara sakral akad nikah, khutbah nikah, nashihat perkawinan, do'a selamat untuk kedua pengantin dan berdo'a (oleh kedua pengantin) pada waktu akan berjima'. Semuanya itu dilaksanakan dalam rangka mempersiapkan lingkungan keluarga yang Islami, yaitu rumah tangga yang rukun dan sekaligus lingkungan yang baik bagi anak yang mungkin akan terkonsepsi pada setiap interaksi berlangsung. Hadits Nabi memberikan kriteria pemilihan jodoh yang baik agar suasana dan kelangsungan rumah tangga dapat sesuai ketentuan Allah:

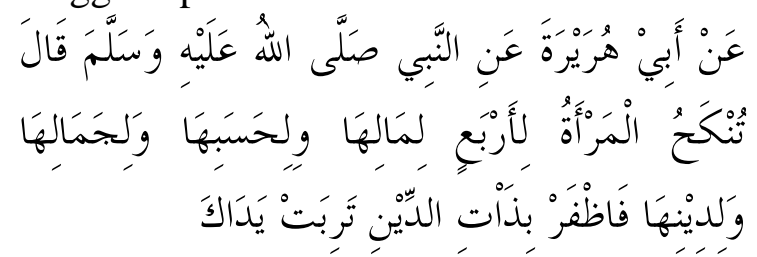

Dari Abi Hurairah, dari Nabi SAW bersabda: "seseorang menikahi perempuan karena empat (perkara): karena hartanya, karena turunannya, karena kecantikanya, dan karena agamanya. Oleh kerena itu dapatilah perempuan yang mempunyai agama, (karena jika tidak) binasalah dua tanganmu". 4

\section{b. Menghormati orang tua}

Ajaran Islam mengenai hormat dan berbakti kepada kedua orang tua sangat inti sifatnya dan, oleh karenanya, berpahala jikalau dipatuhi dan diamalkan serta berdosa, jikalau dilanggar atau diabaikan. Ancaman bagi orang yang tidak hormat pada orang tua ini banyak disebut dalam al-Qur'an, seperti dalam QS al-Isra' (17): 23 juga dalam Hadits Nabi:

${ }^{4}$ Hadits ini diriwayatkan oleh Bukhari dan Muslim. Lihat Bukhari, Shahîh Bukhari: Kitâb alNikâh, juz VIII, hlm. 9; Muslim, Shahîh Muslim, juz I hlm. 236. Tinjauan asbabul wurud: "Diturunkan oleh Ahmad dan Muslim, dari Jabir bin "Abdullah, katanya: " Saya menikahi seorang wanita pada masa Rasulullah masih hidup. Lalu beliau bertanya kepadaku "Ya Jabir, sudah nikah anda? ", dan aku menjawab "Sudah", gadis atau janda? tanya beliau selanjutnya. "Janda", jawabku. "Bukankah sebaiknya anda mencari pasangan gadis", tanya beliau selanjutnya. "Ya Rasulallah, saya mempunyai beberapa orang saudara perempuan, dan saya takut kehadirannya akan memisahkan saya dan saudara-sarudara perempuan saya itu". Mendengar jawaban itu, beliau bersabda: "Wanita itu dinikahi karena agama dan kecantikannya engkau memilih yang memiliki agama, niscaya melimpah ruahlah tanganmu (memperoleh semua yang didambakan).Jalaludin as-Suyuthi, Proses Lahirnya Sebuah Hadits, diterjemahkan dari Asbab Wurud Au al-Luma' fi Asbab al-Hadits, penerjemah: H.O. Taufuqillah dan Afif Muhammad, (Bandung, Pustaka,1985), cet. ke1, hlm. 182 


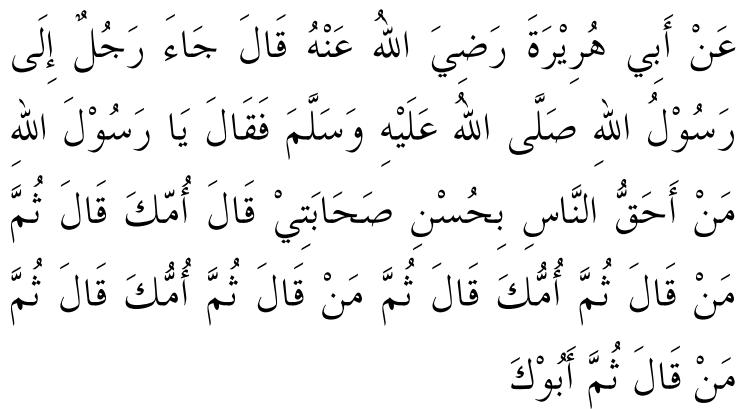

"Dari Abi Hurairah RA berkata: "datang seorang laki-laki Kepada Nabi Muhammad SAW kemudian ia bertanya": "siapa yang diantara manusia yang paling berhak untuk diperlakukan dengan baik?" Nabi berkata; "ibumu", kemudian 3 bertanya lagi" "kemudian siapa?" Nabi berkata: "ibumu", ia bertanya lagi: "kemudian siapa?" Nabi menjawab: "ibumu”, lalu ia betanya lagi: "Kemudian siapa?”, Nabi menjawab : "kemudian bapakmu".

\section{c. Mendo'akan anak}

Setiap orang tua, karenanya, harus selalu berdo'a dan harus dimulai sejak akad nikah dan bersinambung seumur hidup, baik pada setiap kali akan bersetubuh maupun setiap selesai shalat fardhu supaya anaknya ditunjuki Allah sehingga secara berangsur meningkat menjadi manusia yang shaleh:

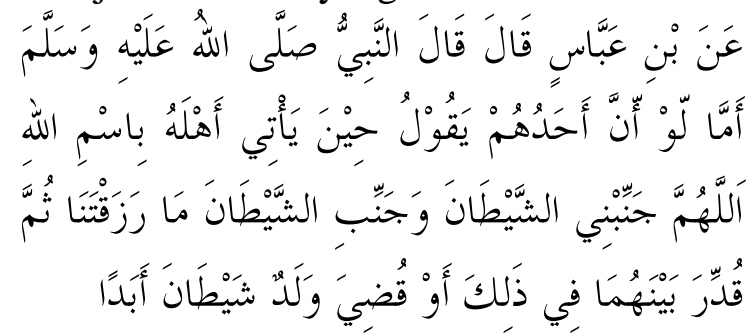

Jika seorang diantara mereka hendak menggauli istrinya, membaca, "Dengan nama Allah. Ya Allah jauhkanlah kami

${ }^{5}$ Hadits ini diriwayatkan oleh Imam Muslim dari jalur sanad yang banyak. Jalur pertama melalui Qutaibah bin Sa'id bin Jamil bin Tharif al-Syaqi, dari Zuhair. Dari jalur Qutaibah. Hadits melalui jalur Abu Kanh Muhammad bin 'Ula al-Hamdani, dari ibn Fadlil dari bapaknya, dari 'Umaroh bin alQ'oqo'a dari Abi Zar'ah dari Abi Hurairah dengan menambahkan: ثم ادناك، ثم ادناك dari syaitan dan jauhkanlah syaitan dari apa yang Engkau karuniakan kepada kami. "Maka andaikan ditakdirkan keduanya mempunyai anak, niscaya tidak ada syaitan yang dapat mencelakakannya". ${ }^{6}$

\section{Langkah-Langkah Pelaksanaan Pendidikan ESQ Anak masa Pra- natal $^{7}$ (Masa Anak dalam Kandungan) Hingga Masa Kelahiran} Langkah-langkah mendidik anak di dalam kandungan, sebagai berikut. Pertama, Mempersiapkan diri dengan cara

${ }^{6}$ Hadits ini terdapat dalam Musnad Ahmad ibn Hambal dan memlalui jalur sanad 'Abdullah dari bapaknya, dari Sufyan dari manshur, dari salim, dari karib dari Ibnu Abas dari Nabi SAW. Hadits di atas juga diriwayatkan oleh Abu dawud dalam Sunannya dengan derajat shahih dengan redaksi yang hampir sama.". Lihat Ahmad bin Hamnbal, Musnad Imam Ahmad bin Hamnbal, Bairut, Darul Fikri, t.t. hlm. 220, lihat juga Imam Hafidz Sulaiman bin Asy'ab as-Sajastani, Shahih Sunan Abi Dawud, Riyad, hlm. 345.

${ }^{7}$ Pada fase prenatal terjadi pertumbuhan yang penting di dalam rahim ibu. Suasana kesehatan dan kejiwaan ibu sangat mempengaruhi pertumbuhan dan perkembangan anak dalam rahimnya. Rangsangan yang diberikan ibu kepada anaknya dalam rahim sangat penting bagi perkembangan selanjutnya. Ibu sebaiknya mengaktifkan komunikasi dengan anak sejak dalam rahim. Memasuki bulan keenam dan ketujuh masa kehamilan, bayi mulai mendengar suara-suara seperti detak jantung ibu, suara usus dan paru-paru, dan juga suara lain di luar rahim. Semua itu didengarkan melalui getaran ketuban yang ada dalam rahim. Suara ibu adalah suara manusia yang paling jelas didengar anak, sehingga suara ibu selalu menjadi suara manusia yang paling disukai anak. Anak menjadi tenang ketika ibunya menepuknepuk perutnya sambil membisikkan kata manis. Hal ini akan menggoreskan memori di otak anak. Semakin sering hal itu diulang semakin kuat guratan itu pada otak anak. Kemampuan mendengar ini sebaiknya digunakan oleh ibu untuk membuat anaknya terbiasa dengan ayat-ayat al-Qur'an. Karena suara ibulah yang paling jelas, maka yang terbaik bagi anak dalam rahim adalah bacaan ayat al-Qur'an oleh ibunya sendiri, bukan dari tape atau radio atu dari yang lain. Semakin sering ibu membaca al-Qur'an selama kehamilan semakin kuatlah guratan memori al-Qur'an di otak anak. 
memilih istri (dan tentu juga suami) yang beragama dalam arti menghayati dan mengamalkannya dengan harapan agar istri dan suami bersama-sama mendidik anakanaknya secara Islami guna mencapai tujuan pendidikan Islam. Kedua, Membina hubungan harmonis antara suami-istri dalam rumah tangga. Islam memerintahkan mu'asyarah bi al-ma'rûf (bergaul dengan baik) antara suami-istri. Pergaulan yang harmonis itu akan memberi kesan positif terhadap anak yang akan dan sedang dikandung. Ketiga, Meningkatkan kasih sayang kepada istri yang sedang mengandung;bakal anak yang harus menyempatkan perhatian sejak dini. Hal tersebut diperlihatkan oleh Nabi SAW ketika istrinya Khadijah telah hamil. Nabi bersabda, "Yang terbaik di antara kamu adalah yang paling baik kepada istrinya" Keempat, Mengajak istri untuk menambah ibadahnya dengan misalnya shalat sunnat, menghadiri pengajian dan sebagainya, dengan begitu orang tua telah membina situasi dan lingkungan yang baik dan Islam untuk anak dalam kandungan. Secara ilmiyah sudah dapat dibuktikan bahwa anak yang masih dalam perut ibunya responsif terhadap lingkungan semacam itu. Kelima, Mengajak istri agar secara bersama-sama atau sendiri-sendiri semakin banyak mendoakan anak yang masih dikandungnya agar Allah menjadikannya baik dan shaleh. Berdoa dalam kondisi semacam itu besar pengaruh dan kesannya dalam kandungan.

\footnotetext{
"'Hadits ini diriwayatkan oleh Thabrani melalui jalur Ahmad bin Ishaq, bin al-Khosyab alRaqt, ia menerima dari Ibrahim bin al-'Ula, mereka dan Isma'il bin 'Iyasy dari 'Amr bin Ru'bah ia dari Abu Kasybah dari Nabi SAW. Dalam jalur sanad di atas terdapat seorang yang bernama 'Amr bin Ru'bah, orang ini ditsiqohakan oleh Ibnu Hiban dan dilemahkan oleh Jamaah. Abu Qosim Sulaiman bin Ahmad at-Tabrani, al-Mu'jam al-Kahir, Juz-22, hlm. 341
}

Setelah anak lahir maka langkahlangkah yang lebih kongkrit harus dilakukan oleh orang tua adalah a) Memperdengarkan azan dan iqamah, b) memberi nama yang baik, aqiqah, memotong rambut, dan khitan c) serta tahnîk dan memberikan makanan dan pakaian yang halal. Penjelasan mengenai hal ini akan diperikan pada pembahasan di bawah ini.

\section{Langkah-Langkah Pelaksanaan Pendidikan ESQ Anak Masa 0 Tahun hingga Remaja}

Setiap orang tua haruslah mengerti akan pertumbuhan dan perkembangan anak, Sehingga ia dapat memberikan stimulasi tumbuh kembang anak yang tepat. Orang tua yang baik juga diharapkan mengetahui Tahap Perkembangan Anak Berdasarkan Usia; terutama ketika anak memasuki fase keemasan (usia 0-6 tahun). Pada usia ini, anak membutuhkan proses pendidikan yang mengarah pada perkembangan intellectual quotient (IQ), emotional quotient (EQ), dan spiritual quotient (SQ) atau ESQ secara seimbang dengan berbagai metode yang tepat. Secara umum, pendidikan anak dapat dibagi pada dua periode. Pertama, masa usia 0-6 tahun. ${ }^{9}$ Periode pertama dalam kehidupan

\footnotetext{
${ }^{9}$ Beberapa ahli juga membagi periode emas (usia 0-6 tahun) ini menjadi beberapa periode. Pertama, usia 0-2 tahun. Kedua, Usia 2 -4 tahun. masa usia ini merupakan masa pembentukan rasa percaya diri, kebanggaan dan dasar-dasar kemandirian., namun belum dapat menerima pendapat orang lain. Pada usia ini si Kecil sudah dapat berjalan, mulai bergerak kesana- kemari dan berbicara untuk mewujudkan keinginannya dalam bentuk ucapan dan perbuatan yang masih bersifat impulsif. Pada awalnya anak masih mempertahankan sifat egosentriknya. Bicaranya pun lebih banyak digunakan untuk kebutuhan dirinya, seperti minta makan, minum dan sebagainya. Oleh karena itu, berilah ia bimbingan dengan penuh kehangatan, kelembutan, kasih sayang dan hindari dari pengalaman yang dapat menimbulkan rasa ragu dan malu. Dengan cara ini,
} 
anak (usia enam tahun pertama) merupakan periode yang amat kritis dan paling penting. Periode ini mempunyai pengaruh yang sangat mendalam dalam pembentukan pribadinya. Apapun yang terekam dalam benak anak pada periede ini, nanti akan tampak pengaruhpengaruhnya dengannyata pada kepribadiannya ketika menjadi dewasa. Karena itu, para pendidik perlu memberikan banyak perhatian pada pendidikan anak dalam periode ini, baik di rumah maupun di sekolah. ${ }^{10}$

anak secara bertahap akan belajar untuk mengendalikan diri. Bila ia berhasil mengendalikan diri tanpa harus kehilangan harga diri, maka akan timbul rasa kebanggaan dan percaya diri yang sangat penting bagi landasan pengembangan psikososialnya pada usia selanjutnya. Sebaliknya bila ia tidak diberi kesempatan untuk dapat mengendalikan diri secara mandiri melainkan terlalu banyak dikendalikan dari luar, maka akan timbul bibit keraguan dan rasa malu berlebihan yang dapat menghambat pengembangan potensipotensinya di kemudian hari. Ketiga, usia 4 - 6 tahun. Usia ini merupakan masa pengembangan inisiatif, meniru norma dan perilaku orang dewasa dan mulai bermasyarakat. Pada usia ini anak akan sangat aktif bergerak, berbicara dan berinteraksi dengan anak lain dan orang yang lebih tua. Ia mulai belajar mengembangkan kemampuannya untuk bermasyarakat, namun masih belum mampu berpikir secara timbal balik. Inisiatifnya juga mulai berkembang dan ia mulai belajar merencakan suatu permainan bersama bersama teman-temanya, berkelompok serta melakukannya dengan gembira. Salah satu konflik yang dapat terjadi adalah timbulnya kebencian pada orang tua yang telah menanamkan pentingnya pengendalian diri pada anak, namun kemudian orang tua itu sendiri ternyata melakukan hal-hal yang tidak boleh dilakukan anaknya (Aisyah 'Abd al-Rahmân alJalâl, al-Muatstsirât al-Salbiyah, 2004, hlm. 43).

${ }^{10}$ Zakiyah Darajat, Berawal dari Keluarga: Revolusi Belajar cara al-Qur'an, Jakarta: Hikmah, 2002, hlm.. 129. Salah satu metode pendidikan alternatif yang kini dikembangkan di Indonesia adalah metode Montessori, hasil pemikiran Dr Maria Montessori yang merupakan ahli pendidikan anak usia dini asal Italia. Metode pendidikan tersebut mengajarkan berbagai pengetahuan dasar dalam kehidupan, melatih gerak motorik halus dan
Kedua, Usia 6 - 12 tahun. Pada periode ini anak menjadi lebih siap untuk belajar secara teratur. Ia mau menerima pengarahan lebih banyak, dan lebih dapat menyesuaikan diri dengan teman-teman sepermainan-nya. Usia ini merupakan masa sekolah, berkarya, tanggung jawab, menyelesaikan tugas dan mampu menerima pendapat yang berbeda. Untuk mewujudkan kecerdasan emosional dan spiritual (ESQ) pada periode ini harus dilakukan secara integrated (satu kesatuan), terencana, terus menerus, dan dilakukan bersama-sama. Usaha tersebut meliputi a) pemberian kasih sayang, b) Pengenalan Allah secara Bertahap, Sederhana, dan Mudah dicerna; c) Pembelajaran dan Pembiasaan Akhlak Mulia; d) Pembelajaran, Pembiasaan, dan Pendisiplinan Ta'at Syari'ah; e) Mengasah Daya Nalar Anak; f) Pengelolaan EmosiIndividual; dan g) Pengelolaan Emosisosial.

\section{a. Pemberian Kasih Sayang}

Memberikan kasih sayang yang diperlukan anak dari pihak kedua orangtua, terutama ibu. Ini perlu sekali, agar anak belajar mencintai orang lain. Jika anak tidak merasakan cintakasih ini, maka akan tumbuh mencintai dirinya sendiri saja dan membenci orang disekitamya. "Seorang ibu yang muslimah harus menyadari bahwa tidak ada suatu apapun yang mesti menghalanginya untuk memberikan

\footnotetext{
kasar, yang kini sudah dipakai di banyak negara. Kalau semula metode tersebut diajarkan dalam bahasa Inggris, maka kemudian dikembangkan dengan memakai bahasa negara masing-masing. Salah satu contohnya adalah Jepang. Karena itu, di Indonesia pun akan dikembangkan model pendidikan serupa dengan bahasa Indonesia di beberapa pendidikan prasekolah sampai sekolah dasar yang sudah menerapkan metode itu di Jakarta. Demikian juga dengan alat peraga, sedapat mungkin dibuat dari bahan lokal yang ada di sekitar sekolah. (TRI)
} 
kepada anak kebutuhan alaminya berupa kasih sayang dan perlindungan. ${ }^{11}$

\section{b. Pengenalan Allah secara Bertahap, Sederhana, dan Mudah dicerna}

Tanamkan Akidah dan Syariah Sejak Dini. Menanamkan akidah yang kokoh adalah tugas utama orangtua. Orangtualah yang akan sangat mempengaruhi tumbuh dan berkembangnya sendi-sendi agama dalam diri anak. Rasulullah saw. Bersabda, "Setiap anak dilahirkan dalam keadaan fitrah. Ibu dan bapaknyalah yang menjadikannya Yahudi, Nasrani, atau Majusi (HR al-Bukhari).

Pada periode ini dikenalkan kepada anak tentang Allah 'Azza Wajalla dengan cara yang sesuai dengan pengertian dan tingkat pemikirannya. Diajarkan kepadanya bahwa 1) Allah Esa, tiada sekutu bagi-Nya; 2) Bahwa Dialah Pencipta segala sesuatu. Pencipta langit, bumi, manusia, hewan, pohon-pohonan, sungai dan lain-lainnya. 3) Cinta kepada Allah, dengan ditunjukkan kepadanya nikmat-nikmat yang dikaruniakan Allah untuknya dan untuk keluarganya.

\section{c. Pembelajaran dan Pembiasaan Akhlak Mulia}

Penanaman akidah pada anak harus disertai dengan pengenalan dan menanamkan al-akhlâq al-karîmah seperti berbakti kepada orangtua, santun dan sayang kepada sesama, bersikap jujur, berani karena benar, tidak berbohong, bersabar, tekun bekerja, bersahaja, sederhana, dan sifat-sifat baik lainnya. Semua itu dikerjakan semua semata-mata untuk meraih ridha Allah, bukan untuk mendapatkan pujian atau pamrih duniawi.

\section{d. Pembelajaran, Pembiasaan, dan Pendisiplinan Ta'at Syari'ah}

Proses pembelajarannya dapat dimulai dengan memotivasi anak untuk senang melakukan hal-hal yang dicintai

${ }^{11}$ Muhammad Quthub, Manhaj al-Tarbiyah alIslamiyah, juz 2, hlm. 134. oleh Allah, misalnya, dengan mengajak shalat, berdoa, atau membaca al-Quran bersama. Pembiasaan bagi ibadah mahdah ini seperti hendaknya dilakukan secara continue, dan bimbingan yang komprehensif dengan menentukan berbagai metode dan tatacara yang disesuaikan dengan kematangan dan perkembangan kejiwaanya.

\section{1) Pengajaran Baca al-Qur'an}

Masa kanak-kanak merupakan fase yang paling subur untuk melakukan pembinaan keilmuan dan pemikiran. Pada masa ini daya tangkap dan daya serap otak mereka berada pada kemampuan maksimal; dada mereka lebih longgar dan lebih hapal terhadap apa yang mereka dengar. $^{12}$ Dari hal ini, mungkin timbul pertanyaan bagaimana dapat di usia mereka yang masih belia telah dapat menghapal al-Qur'an. Jawaban yang pasti adalah karena keutamaan yang diberikan Allah pada mereka yang mau berusaha. ${ }^{13}$ Sebagai contoh adalah adalah apa yang terjadi pada Imam Syafi'i berkata: “Aku telah menghapal al-Qur'an pada umur 7 tahun dan aku hapal Al Muwaththa' (karya Imam Malik) pada umur 10 tahun." 14

\footnotetext{
${ }^{12} \mathrm{Abu}$ Hurairah ra. meriwayatkan secara marfû', bahwa Rasulullah saw. bersabda (yang artinya), "Siapa yang mempelajari al-Quran ketika masih muda, maka al-Quran itu akan menyatu dengan daging dan darahnya. Siapa yang mempelajarinya ketika dewasa, sedangkan ilmu itu akan lepas darinya dan tidak melekat pada dirinya, maka ia mendapatkan pahala dua kali" (HR alBaihaqi, al-Dailami, dan al-Hakim).

Dalam al-Qur'an, Allah swt. berfirman: ${ }^{13}$

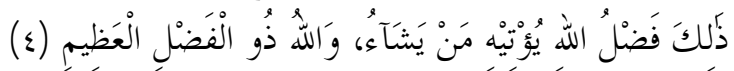

"Demikianlah keutamaan dari Allah, diberikannya kepada siapa yang Dia kehendaki dan Allah-lah yang memiliki keutamaan yang besar." QS. al- Jumuah ayat 4.

Para salaf dahulu pun sangat memperhatikan pendidikan tahfizh al-Qur'an bagi anak-anak mereka. ${ }^{14}$ Syaikh Yasin bin Yusuf al-Marakisyi menceritakan tentang imam al-Nawawi, katanya: "Aku melihat beliau ketika masih berumur 10 tahun
} 
2) Pembiasaan Shalat:

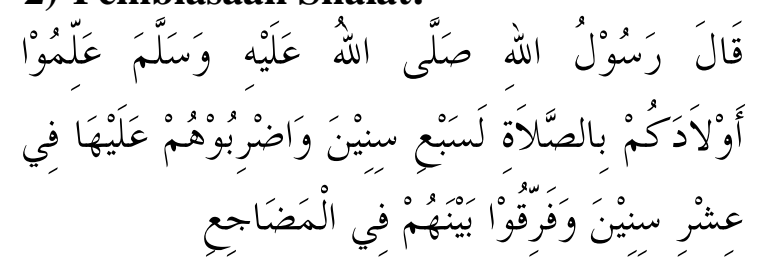

Rasulullah saw. bersabda, "Ajarkanlah kepada anak-anak kalian shalat ketika telah menginjak usia tujuh tahun, dan pukulah kepadanya apabila telah menginjak usia sepuluh tahun dan pisahkanlah (sapihlah) tempat tidurnya dengan kalian”. (H.R. Abu Dawud). ${ }^{15}$

\section{3) Pembiasaan Shaum}

Puasa merupakan kewajiban bagi setiap orang mu'min. ${ }^{16}$ yang baligh, berakal dan tidak dalam sedang pepergian, dan bagi wanita tidak sedang haidh dan nifas. $^{17}$ Sebagai ibadah wajib ia membutuhkan kesiapan yang baik secara pemahaman maupun pelaksanaan, maka ibadah puasa harus dibiasakan pengamalannya.

\section{4) Pengajaran Sebagian Hukum Yang Jelas dan Tentang Halal-Haram}

Anak-anak harus diajarkan untuk menutup aurat, berwudhu, hukum-hukum

di Nawa. Para anak kecil tidak mau bermain dengannya dan iapun berlari dari mereka seraya menangis, kemudian ia membaca al-Qur'an. Maka tertanamlah dalam hatiku rasa cinta kepadanya. Ketika itu bapaknya menugasinya menjaga toko, tetapi ia tidak mau bejualan dan menyibukkan diri dengan al-Qur'an. Maka aku datangi gurunya dan berpesan kepadanya bahwa anak ini diharapkan akan menjadi orang yang paling alim dan zuhud pada zamannya serta bermanfaat bagi umat manusia. Ia pun berkata kepadaku: Tukang ramalkah Anda? Jawabku: Tidak, tetapi Allah-lah yang membuatku berbicara tentang hal ini. Bapak guru itu kemudian menceritakan kepada orangtuanya, sehingga memperhatikan beliau dengan sungguh-sungguh sampai dapat khatam alQur'an ketika menginjak dewasa."

${ }^{15}$ Abu Dawud, Sunan Abu Dawud, Kitâb alShalâh, Jilid I, hlm. 242-243.

${ }^{16}$ Q.s. Al-Baqarah, 2: 183-184:

17 Sayid Sabiq, Fiqh al-Sunnah, Beirut, Libanon, 1983/1403H), Jilid I, hlm. 380.
Islam. Anak diberitahu dari hal-hal yang haram, dusta, adu domba, mencuri dan melihat kepada yang diharamkan Allah. Anak dibimbing untuk menetapi syariat Allah, sehingga anak akan tumbuh demikian dan menjadi terbiasa. Karena bila semenjak kecil anak dibiasakan dengan sesuatu, maka kalau sudah dewasa akan menjadi kebiasaannya. Agar diupayakan pula pengajaran ilmu pengetahuan kepada anak, sebagaimana kata Sufyan al-Tsauri: "Seorang bapak harus menanamkan ilmu pada anaknya, karena dia penanggung jawabnya." ${ }^{18}$

\section{a. Mengasah Daya Nalar Anak}

Adalah penting untuk menanamkan kebiasaan anak menerima segala sesuatu melalui proses 'berpikir'. Dengan itu, anak dapat memahami informasi yang diterimanya, yang akan mendorong-nya melakukan perbuatan sesuai dengan apa yang telah dipahaminya tersebut. Hal ini termasuk agar pelaksanaan hukum-hukum ini dapat dilakukan dengan baik dan konsisten, proses penerimaan anak terhadap hukum tersebut mestilah dilandasi keimanan kepada Allah Swt, Rasul-Nya maupun al-Quran, dan pemahaman serta penalaran yang benar.

1) Pembelajaran dan Pembiasaan Gemar Untuk Mencari Ilmu. Agar para orang tua dapat mengarahkan anak melangkah menuju ilmu, belajar, serta mencintai ilmu dan ulama, ada beberapa hal penting yang harus ditempuh: 1) Tanamkan bahwa menuntut ilmu adalah perintah Allah Swt. ${ }^{19}$ 2) Tanamkan bahwa al-Quran

${ }^{18}$ Muhammad Hasan Musa, Nuzharul Fudhala' Tahdzib Siar A'lamin Nubala, Juz 1, hlm. 67.

${ }^{19}$ Kecintaan anak kepada Allah, yang seyogyanya sudah terlebih dulu ditanamkan, akan memunculkan ketaatan pada perintah-Nya dan takut akan azab-Nya, termasuk dalam menuntut ilmu. Cinta dan takut kepada Allah akan memunculkan 
adalah sumber kebenaran dan standard semua kebenaran. 3) Ajarkan metode belajar yang benar menurut Islam. $\left.{ }^{20}, 4\right)$ belajarlah dengan memperbanyak praktek dan meyedikitkan aspek teoritis $^{21}$; 5) Memilihkan guru dan sekolah yang baik bagi $\operatorname{anak}^{22} ; 6$ )

sikap konsisten dalam mencari ilmu tanpa bosan dan dihinggapi rasa putus asa.

${ }^{20}$ Syaikh Taqiyuddin al-Nabhani menjelaskan dalam kitab al-Syakhshiyah alIslâmiyyah jilid 1, bahwa Islam mengajarkan metode belajar yang benar, yaitu: 1. Mempelajari sesuatu dengan mendalam hingga dipahami apa yang dipelajari dengan benar. 2. Meyakini ilmu yang sedang dipelajari hingga dapat dijadikan dasar untuk berbuat. 3. Sesuatu yang dipelajari bersifat praktis, bukan sekadar teoretis, hingga dapat menyelesaikan suatu masalah.

${ }^{21}$ Dalam mempelajari alam semesta, misalnya, dikatakan secara teoretis bahwa bulan mengelilingi bumi. Untuk menjadikannya sebagai pemahaman yang mendalam haruslah anak diajak melihat fakta bulan, yang dari hari ke hari berubah bentuk dan besarnya. Dengan demikian, anak pun menjadi yakin bahwa perubahan tanggal setiap harinya adalah karena peredaran bulan. Dengan begitu, ia dapat mengetahui bahwa menentukan tanggal satu Ramadhan, misalnya, adalah dengan melihat bulan.

${ }^{22}$ Ibnu Sina dalam kitabnya, al-Siyâsah, mengatakan, "Seyogyanya seorang anak itu dididik oleh seorang guru yang mempunyai kecerdasan dan agama, piawai dalam membina akhlak, cakap dalam mengatur anak, jauh dari sifat ringan tangan dan dengki, dan tidak kasar di hadapan muridnya." Imam Mawardi (dalam Nashîhah al-Mulûk hlm. 172) menegaskan urgensi memilih guru yang baik dengan mengatakan, "Wajib bersungguh-sungguh di dalam memilihkan guru dan pendidik bagi anak, seperti kesungguhan di dalam memilihkan ibu dan ibu susuan baginya, bahkan lebih dari itu. Seorang anak akan mengambil akhlak, gerak-gerik, adab dan kebiasaan dari gurunya melebihi yang diambil dari orangtuanya sendiri." Begitupun memilihkan sekolah yang baik yang di dalamnya diajarkan halhal yang tidak bertentangan dengan agama, apalagi yang merusak akidah anak-anak Muslim. Banyak orangtua memilih sekolah untuk anaknya sekadar agar anak dapat memperoleh ilmu dan prestasi yang bagus, tetapi lupa akan perkembangan kekokohan akidah dan akhlaknya. Namun demikian, tentulah guru yang paling pertama dan utama adalah
Mengajari anak untuk memuliakan para ulama; 7) Memmbiasakan seluruh keluarga membaca dan menghapal ayat-ayat al-Quran dan Hadis Nabi saw; 8) Membuat perpustakaan rumah, sekalipun sederhana; 9) Mengajak anak menghadiri majelis-majelis kaum dewasa. $^{23}$ Dengan membawa anakanak ke majelis orang dewasa, akalnya akan meningkat, jiwanya akan terdidik, semangat dan kecintaannya kepada ilmu akan semakin kuat.

2) Membina dan Mempertahankan Kreativitas Anak. Kreativitas dibutuhkan oleh manusia untuk menyelesaikan berbagai masalah dalam kehidupan sehari-hari. Kreativitas harus dikem-bangkan sejak dini. Ditinjau dari segi ajaran Islam maka pendidikan kreatifitas ditemukan sumbernya dalam berbagai Hadits yang memberi penjelasan tentang metode Rasul Allah dalam menghadapi cucucucunya dan anak-anak lainnya, metode-metode tersebut, antara lain, adalah: a) Membina keakraban antara orang tua dan anak dalam rumah tangga; b) Memberi kesempatan luas kepada anak, terutama yang masih kecil, untuk bcrmain-main, baik sendirian maupun ber-kelompok dengan teman-temannya. Di dalam hadits yang diriwayatkan oleh alTirmidzi terdapat penjelasan bahwa kebebasan bermain-main anak-anak diwaktu kecil akan mening-katkan

orangtuanya, dan sekolah yang paling pertama dan utama adalah rumah tempat tinggalnya bersama orangtua.

${ }^{23} \mathrm{Nabi}$ SAW. pernah menceritakan bahwa beliau ketika masih kecil juga turut menghadiri majelis-majelis kaum dewasa. Beliau mengatakan: "Aku biasa menghadiri pertemuan-pertemuan para pemuka kaum bersama paman-pamanku...." (Diriwayatkan oleh Abu Ya'la dengan sanad sahih dalam Musnad-nya [2/157] dan oleh Ahmad [1/190]). 
daya kreatifitasnya diwaktu dia telah meningkat dewasa; c) Menggembirakan anak, di dalam sebuah Hadits yang diriwayatkan oleh Al-Thabrani ditemukan penjelasan bahwa Nabi SAW, ketika melihat Husain bermain-main dengan temannya, segera berlari-lari bersama mereka dan, karena gembiranya, lalu menangkap Husain dan menciumnya. ${ }^{24}$

b. Pengelolaan Emosi-Individual

1) Membentuk dan Membina Kemandirian Anak. Untuk membentuk kemandirian anak dan mencegh ketidakmandirian anak, ada beberapa hal yang perlu dilakukan oleh orang tua sebagai berikut. Pertama: memberikan pemahaman kepada anak sesuai dengan tingkat perkem-bangan (kemampuan) akalnya. Kedua: berbuatlah secara bijaksana. Ketiga: memberikan kasih sayang secara wajar; dalam perilaku, hadiah, maupun pujian. Keempat, memberikan cara pendidikan secara tegas kepada anak.

2) Pengembangan Rasa Percaya Diri dan Tanggung Jawab dalam Diri Anak . Anak-anak sekarang ini adalah pemimpin hari esok. Karena itu, mereka harus dipersiapkan dan dilatih mengemban tanggung jawab dan melaksanakan tugas yang nantinya akan mereka lakukan. Hal itu dapat direalisasikan dalam diri anak melalui pembinaan rasa percaya diri, penghargaan jati dirinya, dan diberikan

\footnotetext{
${ }^{24} \mathrm{Di}$ pihak lainnya, beberapa kondisi yang dapat menghambat perkembangan daya kreatifitasnya anak harus dihindarkan. Diantaranya adalah: (1) melarang anak dari banyak bertanya, (2) mengawasi anak terlalu ketat (3) pembagian kerja yang terlalu rutin dalam keluarga, (4) menyediakan alat-alat permainan yang terlalu terstuktur (5) melarang anak berfantasi (atau mengkhayal) (6) sikap orang tua yang terlalu konservatif (7) perlindungan atau pemberian kebebasan yang belebihan (8) pendisiplinan yang terlalu kaku dan otoriter.
}

kepada anak kesempatan untuk menyampaikan pendapatnya dan apa yang terbetik dalam pikirannya, serta diberikan kepadanya dorongan agar mengerjakan urusannya sendiri, bahkan ditugasi dengan pekejaan rumah tangga yang sesuai untuknya.

3) Kebiasaan Tertib dan Teratur. Pembiasaan tersebut memerlukan konsistensi (istiqâmah), ketertiban, keteraturan, dan kedisiplinan. Pembinaan membiasakan diri tertib dan teratur harus dimulai anak sejak usia dini, dan harus dimulai dari hal yang paling sederhana dan yang paling sering ia lakukan. Misalnya: (1) pembiasaan makan, minum dan tidur teratur, (2) biasakan bergaul dengan teman teman yang baik dan rajin, (3) membiasakan bersih dan sehat, (4) membiasakan anak berakhlak baik.

\section{c. Pengelolaan Emosi-Sosial}

1) Membina Kemampuan Bersosialisasi. Pada dasarnya setiap anak mempunyai potensi dan kemampuan untuk bersosialisasi, tinggal bagaimana para orang tua dan orang-orang yang dekat dengan anak berupaya untuk mengasahnya. Hal ini dapat dilakukan dengan beberapa hal sederhana berikut: 1)Sesering mungkin anak diajak berkomunikasi, misalnya ketika ia sedang menangis atau marah-marah; tanyakan apa yang membuatnya marah, kemudian diarahkan supaya sang anak mencari solusinya. 2) Melatih anak untuk peka terhadap lingkungannya, misalnya ketika temannya marah kepadanya, anak diajarkan untuk menghadapi-nya dengan tenang, lalu menanyakan masalahnya dan mau meminta maaf jika ia yang bersalah; 3 ) orang tua menghindari memanjakan anak secara berlebihan, karena hal ini akan menjadikannya kurang tangguh ketika ia ditimpa dengan berbagai masalah. 
2) Melatih Sikap Pro-Aktif ${ }^{25}$. Proaktif merupakan kebalikan reaktif. Bila reaktif tidak mampu memilih respon, maka proaktif adalah kemampuan seseorang untuk memilih respon. Sikap proaktif adalah sikap seseorang yang mampu membuat pilihan dikala mendapatkan rangsangan (stimulus). Sikap proaktif sangat berguna bagi manusia terutama dalam menghadapi rintangan maupun dalam berinteraksi dengan manusia lain. Sikap proaktif menunjukkan tingkat kecerdasan emosi (EQ) yang tinggi. Seseorang dapat bertahan saat menghadapi musibah, dapat menumbuhkan motivasi saat kondisi tidak menyenangkan, juga dapat memberikan respon positif yang disesuaikan dengan situasi, semua itu merupakan sikap proaktif yang menunjukkan pengelolaan emosi secara baik.

3) Menumbuhkembangkan Rasa Empati Anak. Berikut ini adalah beberapa cara untuk menumbuhkan empati pada anak. Pertama, berikan teladan. Anak adalah duplikasi dari orang tuanya. Jika orang tua berbuat baik, maka anak biasanya juga akan berbuat baik. Tunjukkan kepedulian orang tua

\footnotetext{
${ }^{25}$ Stephen Covey, penulis Seven Habits of Highly Effective People, membuat istilah baru sebagai lawan dari sikap reaktif, yaitu sikap "proaktif". Sikap reaktif adalah sikap seseorang yang gagal membuat pilihan respon dikala mendapatkan rangsangan (stimulus). Sederhananya adalah, bila seseorang selalu menjadi marah kalau dihina, maka orang tersebut dikatakan "reaktif" karena selalu memberikan tanggapan (respon) yang sama terhadap suatu rangsangan (stimulus). Binatang secara umum adalah makhluk yang reaktif. Bila Anda pukul, reaksinya hanya dua, takut atau marah. Suatu tanggapan yang mudah diduga sebelumnya. Proaktif merupakan kebalikan reaktif. Bila reaktif tidak mampu memilih respon, maka proaktif adalah kemampuan seseorang untuk memilih respon. Sikap proaktif adalah sikap seseorang yang mampu membuat pilihan dikala mendapatkan rangsangan (stimulus).
}

terhadap orang-orang yang tak mampu. Komitmen orang tua yang kuat dalam membantu meringankan beban penderitaan orang lain insya Allah dapat menular kepada anak-anak. Kedua, tidak membatasi pergaulan anak. Sering kali teman yang kesusahan menjadi jembatan yang dapat membukakan mata terhadap hal-hal yang kurang dipedulikan. Ketiga, Doronglah anak untuk menunjukkan empatinya kepada orang lain dengan pembiasaan sedekah. Sedekah termasuk amal shaleh, yang terwujud dalam berbagai hal yang bersifat sosial dengan sedekah termasuk zakat, merupakan kegiatan yang dianjurkan bahkan diwajibkan. Hal tersebut bila tidak dimulai sejak dini, mereka secara psikologis tidak akan memiliki kegemaran untuk mengeluarkan sedekah. Keempat, Jika memungkinkan, ajaklah anak melihat sendiri atau mengalami kehidupan yang sangat berbeda dengan kehidupan yang biasa ia jalani. Ajaklah anak-anak untuk mengunjungi tempat di mana banyak orang susah yang berkumpul di sana. Dengan itu mereka akan melihat ada sisi lain dari kehidupan manusia. Orang tua pun dapat memberi pemahaman kepada mereka dengan menjelaskan mengapa ada gelandangan yang mengais-ngais sampah, atau makan makanan yang telah dibuang ke tempat sampah, dan sebagainya.

\section{Langkah-Langkah Pendidikan ESQ pada Masa Remaja}

Masa remaja dikenal dengan masa storm and stress di mana terjadi pergolakan emosi yang diiringi dengan pertumbuhan fisik yang pesat dan pertumbuhan secara psikis yang bervariasi. Pada masa remaja (usia 12 sampai dengan 21 tahun) terdapat beberapa fase, fase remaja awal (usia 12 tahun sampai dengan 
15 tahun), remaja pertengahan (usia 15 tahun sampai dengan 18 tahun) masa remaja akhir (usia 18 sampai dengan 21 tahun) dan diantaranya juga terdapat fase pubertas yang merupakan fase yang sangat singkat dan terkadang menjadi masalah tersendiri bagi remaja dalam menghadapinya. Fase pubertas ini berkisar dari usia 11 atau 12 tahun sampai dengan 16 tahun dan setiap individu memiliki variasi tersendiri. Masa pubertas sendiri berada tumpang tindih antara masa anak dan masa remaja, sehingga kesulitan pada masa tersebut dapat menyebabkan remaja mengalami kesulitan menghadapi fase-fase perkem-bangan selanjutnya. Pada fase itu remaja mengalami perubahan dalam sistem kerja hormon dalam tubuhnya dan hal ini memberi dampak baik pada bentuk fisik (terutama organ-organ seksual) dan psikis terutama emosi.

Metode pendidikan yang harus dipraktekan bagi anak anak yang sudah atau menjelang usia baligh adalah sebagai berikut. Pertama, Metode Diskusi, metode diskusi maksudnya adalah bahwa setiap pelajaran dan pendidikan yang disampaikan kepada anak disampaikan dengan bertukar pikiran, metode ini tidak lagi bernuansa pemberian materi secara langsung akan tetapi dilakukan dengan metode interaktif antara orang tua dan anak. Diskusikan berbagai persoalan dengan perspektif ruhaniah. Melihat dari perspektif ruhaniah artinya memberikan makna dengan merujuk pada Rencana Agung Ilahi (Divine Grand Design). ${ }^{26}$

Kedua, Metode Pemberian Peran dan Pendampingan. Metode ini adalah upaya melatih anak untuk melakukan sesuatu berupa tugas dan tanggung jawab, Tugas tersebut bersipat umum baik hal yang berkenaan dengan masalah sikap dan nilai atau hal yang berkenaan dengan masalah

\footnotetext{
26Jalaluddin Rakhmat, Belajar Cerdas, Bandung: MLC, 2005, hlm. 43.
}

materi dan kemampuan berbuat. Keempat, Metode pengawasan. Hal yang tidak dapat diabaikan oleh para orang tua pada masa ini adalah pengawasan.

Beberapa hal yang perlu menjadi perhatian bagi orang tua dalam mengawasi anak-anaknya adalah dalam beberapa hal misalnya; (a) Orang tua hendaknya mengawasi tempat dan teman bermain si anak, (b) mengawasi selama kegiatan mereka di rumah, (c) mengawasi pekerjaan rumahnya, (d) mengawasi kegiatan ia setelah pulang dari sekolah, (e) mengawasi buku bacaan dan tontonan yang suka ditontonya, (f) mengawasi pelaksanaan ibadahnya dan akhlaknya, (g) mengawasi perkembangan kejiwaannya, setiap menusia biasanya memiliki kecenderungan dan sifat-sifat tertentu, bila terjadi kecenderungan yang terlalu berlebihan pada sifai-sifat tertenlu maka itu akan menyebabkan hal yang tidak baik bagi kejiwaan si anak, misalnya anak terlalu pemalu maka ia akan mengasingkan diri sehingga anak akan hilang kepercayaan dirinya, sebaliknya bila anak lerlalu berani, maka kecendrungan anak itu akan nakal dan bandel. Berbagai sifat kejiwaan manusia hendaknya diarahkan sesuai dengan porsi yang seharusnya dan sewajarnya sehingga kejiwaan anak berjalan dengan seimbang.

\section{Penutup}

Orang tua berperan dan mereka diminta tanggung jawab, komitmen, dan konsistensinya dalam pendidikan anak, ada beberapa langkah dalam pembentukan ESQ: Langkah-Langkah Persiapan (Masa Sebelum Mengandung), Di antara langkahlangkah a) memilih pasangan hidup yang seiman dan shaleh (shalehah), b) menghormati orang tua, dan c) mendo'akan (calon) anak. Langkah-Langkah Pelaksanaan Pendidikan ESQ Anak masa Pra-natal (Masa Anak dalam Kandungan) Hingga Masa Kelahiran, Pertama, 
Mempersiapkan dini dengan cara memilih istri suami yang beragama dalam arti menghayati dan mengamalkannya dengan harapan agar istri dan suami bersama-sama mendidik anak-anaknya secara Islami. Kedua, Membina hubungan harmonis antara suami-istri dalam rumah tangga. Ketiga, Meningkatkan kasih sayang kepada istri yang sedang mengandung, Keempat, Mengajak istri untuk menambah ibadah. Kelima, Mengajak istri agar secara bersama-sama banyak mendoakan anak yang masih dikandungnya agar Allah menjadikannya baik dan shaleh. Langkah pelaksanaan pendidikan anak setelah lahir pra-remaja; Setelah anak lahir maka langkah yang lebih kongkrit harus dilakukan oleh orang tua adalah a) Memperdengarkan azan dan iqamah, b) memberi nama yang baik, aqiqah, memotong rambut, dan khitan c) serta tahnîk dan memberikan makanan dan pakaian yang halal.

Langkah-Langkah Pelaksanaan

Pendidikan ESQ Anak Masa 0 Tahun hingga Remaja, Untuk mewujudkan kecerdasan emosional dan spiritual (ESQ) pada periode ini harus dilakukan secara integrated, usaha tersebut meliputi a) pemberian kasih sayang, b) Pengenalan Allah secara Bertahap, Sederhana, dan Mudah dicerna; c) Pembelajaran dan Pembiasaan Akhlak Mulia; d) Pembelajaran, Pembiasaan, dan Pendisiplinan Ta'at Syari'ah; e) Mengasah Daya Nalar Anak; f) Pengelolaan EmosiIndividual; dan g) Pengelolaan Emosisosial.

\section{DAFTAR PUSTAKA}

Al-Qur'an dan Tafsirnya, Kementrian Agama RI. Jakarta: Widya Cahaya, 2011.

Abd al-Rahmân al-Nahlawi, Pendidikan Islam di Rumah, Sekolah, dan Masyarakat, terjemahan oleh Sihabuddin, Jakarta, Gema Insani Press, 1995,

Ahmad bin Hamnbal, Musnad Imam Ahmad bin Hamnbal, Bairut, Darul Fikri, t.t.

Aisyah 'Abd al-Rahmân al-Jalâl, alMuatstsirât al-Salbiyah, 2004,

Jalaluddin Rakhmat, Belajar Cerdas, Bandung: MLC, 2005,

Muhammad Quthub, Manhaj al-Tarbiyah al-Islamiyah, juz 2,

Muhammad Hasan Musa, Nuzharul Fudhala' Tahdzib Siar A'lamin Nubala, Juz 1,

Imam Hafidz Sulaiman bin Asy'ab asSajastani, Shahih Sunan Abi Dawud, Riyad,

Sayid Sabiq, Fiqh al-Sunnah, Beirut, Libanon, 1983/1403H), Jilid I,

Zakiyah Darajat, Berawal dari Keluarga: Revolusi Belajar Cara al-Qur'an, Jakarta, Hikmah, 2002, cetakan ke-1. 